\title{
Analisis Perilaku Kekerasan Fisik Dan Psikologis Kelompok Resiko Lanjut Usia Penghuni Lembaga Pemasyarakatan Kelas I
}

\author{
Yuliati $^{1}$, Petrus Nugroho ${ }^{2}$, Herry Prasetyo ${ }^{3}$ \\ 1. Universitas Esa Unggul \\ 2. Poltekkes Kemenkes Semarang \\ 3. Poltekkes Kemenkes Semarang
}

Email:parmawatiherni@yahoo.com

\begin{abstract}
Abstrak
Latar belakang: Perilaku perlindungan lanjut usia merupakan aktivitas yang diarahkan untuk mengurangi risiko individu terhadap perkembangan penyakit atau masalah kesehatan tertentu. Lembaga pemasyarakatan menjadi tempat yang berisiko tinggi terhadap perilaku kekerasan fisik, psikologis pada lansia. Tujuan penelitian: adalah untuk mengetahui perilaku kekerasan fisik dan psikologis pada lansia yang terdapat di lembaga pemasyarakatan.

Metode penelitian: metode yang digunakan dalam penelitian ini adalah deskriptif research tanpa kelompok kontrol. Adapun populasi penelitian yaitu penghuni Lembaga Pemasyarakatan kelas 1, sedangkan sampel penelitian ini dipilih dengan kriteria inklusi kelompok lanjut usia baik lansia muda usia 60-69 tahun dan lansia tua $>70$ tahun. Selanjutnya, berdasarkan analisa data, hasil penelitian disajikan dalam bentuk distribusi frekuensi dan proporsi. Hasil penelitian: menunjukkan narapidana lansia dengan suku Sunda dan Tionghoa memiliki angka kekerasan fisik lebih tinggi dibandingkan suku lainnya. Lansia dengan suku Sunda terjadi kekerasan fisik sebesar 52,94\% dan Tionghoa sebesar 66,77\%. Sedangkan, angka kekerasan psikologis yang terjadi pada narapidana lansia sebesar $36,11 \%$ dan 63,89\% tak terjadi. Simpulan dan saran: kekerasan fisik sering kali terjadi pada narapidana lansia daripada kekerasan psikologis. Petugas kesehatan lapas harus memperhatikan status kesehatan secara fisik dan psikolog harus melakukan konseling secara berkala.
\end{abstract}

Kata Kunci: Fisik; Kekerasan; lansi; psikologis

\section{Analysis Physical And Psychological Violent Behavior Risk Group Of Elderly Residents Correctional Institution Class I}

\begin{abstract}
Background: The behavior protection of the elderly is an activity that is directed to reduce an individual's risk of disease progression or specific health problems. Correctional institution becomes a high risk of violent behavior of physical, psychological towards the elderly.

The research objective: is to know the behavior of physical and psychological abuse towards the elderly who are in prisons.

The research method: the method used in this research is descriptive research without the control group. The population are inhabitants of correctional institution grade 1, while the sample in this study were selected with the inclusion criteria young elderly 60-69 years and old elderly > 70 years. Furthermore, the results are presented in the form of frequency distribution and proportion.

The result of research: shows that elderly inmates with Sundanese and Chinese have a number of physical violence is higher than other tribes. Elderly with Sundanese physical violence amounted to 52.94\% and amounted to $66.77 \%$ Chinese. Meanwhile, the rate of psychological violence that occurs in elderly inmates amo unted to $36.11 \%$ and $63.89 \%$ did not happen.

Conclusions and suggestions: physical violence often occurs in elderly inmates than psychological violence. Prison health workers should pay attention to physical health status and psychologists should conduct regular counseling.
\end{abstract}

Jurnal SMART Keperawatan Sekolah Tinggi Ilmu Kesehatan (STIKes) Karya Husada Semarang www.stikesyahoedsmg.ac.id/ojs/index.php/sjkp(perawat) 
Keywords: elderly; psychological; physical; violence

Pendahuluan

Penuaan pada lanjut usia (lansia) merupakan suatu hal yang pasti. Undang-undang nomor 13 tahun 1998 tentang kesejahteraan lanjut usia mendefinisikan lanjut usia sebagai seseorang yang telah mencapai usia 60 tahun atau lebih. Definisi penuaan berdasarkan teori psikologis adalah perubahan sikap dan perilaku lansia karena pengalaman hidup dan faktor psikologi lansia tersebut. Peningkatan jumlah lansia mengindikasikan adanya keberhasilan pembangunan dalam bidang kesehatan (Komisi Nasional Lanjut Usia, 2010).

Indonesia merupakan negara ke empat dengan jumlah lansia terbesar di Asia setelah Cina, India, dan Jepang (UN, 2012). Jumlah lansia di Indonesia setiap tahunnya pun mengalami peningkatan. Tahun 2005 jumlah lansia mencapai 16,80 juta orang, angka ini meningkat pada tahun 2007 menjadi 18,96 juta orang. Tahun 2009 jumlah lansia mengalami peningkatan kembali menjadi 19,32 juta orang atau 8,37 persen dari total keseluruhan penduduk Indonesia (Komnas Lansia, 2010). Stanley (2002) kebijakan pemerintah dalam meningkatkan kesejahteraan lansia memiliki implikasi yang besar secara keseluruhan termasuk perlindungan. Perilaku perlindungan lansia adalah aktivitas yang diarahkan untuk mengurangi risiko individu terhadap perkembangan penyakit atau masalah tertentu. Lansia merupakan individu yang termasuk dalam kelompok berisiko (Daphne, 2011).

Lansia merupakan kelompok berisiko yang dapat menjadi kelompok rentan. Kelompok rentan berhubungan dengan gabungan beberapa faktor sosial, personal, situasional dan lingkungan. Faktor-faktor tersebut dapat mengakibatkan peningkatan kerentanan terhadap kekerasan. Faktor lain yang menyebabkan seorang lansia menjadi kelompok rentan apabila tidak adanya kerabat dekat atau dukungan orang lain yang mampu dan bersedia untuk memberikan bantuan (Miller, 2012).

Tempat sosial berisiko tinggi terjadinya kekerasan pada lansia seperti ruangan single di hotel, penginapan sementara atau asrama, jalan dan lembaga pemasyarakatan (Kosberg, 2014). Kondisi lembaga pemasayarkatan di Indonesia masih belum dikatakan baik. Sistem Database Pemasyarakatan merilis pada tahun 2014 terdapat 25 lembaga pemasyarakatan yang mengalami kelebihan kapasitas (over capacity) dari 33 lembaga pemasyarakatan yang ada di Indonesia. Lembaga pemasyarakatan di Indonesia membedakan lapas berdasarkan usia yang terdiri dari 
lapas anak-anak dan dewasa (Undang-undang nomor 12 tahun 1995), sehingga narapidana lansia bergabung dalam lapas dewasa. Hal tersebut dapat menjadikan faktor risiko terjadinya masalah pada narapidana lansia, seperti kekerasan, pemerasan, dan suap (Liwarti, 2013).

Lembaga pemasyarakatan menjadi tempat yang berisiko tinggi terhadap perilaku kekerasan fisik, psikologis dan ekonomi pada lansia (Kosberg, 2014). Selain itu lansia mengalami peningkatan masalah kesehatan fisik dan mental di lembaga pemasyarakatan (Keohane, Sed, Sterns A., Lex, Sterns. R., 2008). Masalah-masalah yang terjadi pada lansia di lembaga pemasayarakatan anatara lain, gangguan sistem tubuh, gangguan mental atau stres dan hal-hal yang berhubungan dengan kekerasan (Burbenk \&Smyer, 2009).

Penuaan yang terjadi pada lansia menjadikan mereka sebagai kelompok berisiko, kelompok berisiko tersebut dapat menjadi kelompok rentan apabila terdapat keterbatasan lain, seperti lingkungan yang tidak mendukung. Kelompok rentan dan berisiko membutuhkan satu atau lebih kebutuhan lainnya yang berdampingan dengan pemenuhan kebutuhan dasar, seperti komunikasi, perawatan medis, pemeliharaan kebebasan, pengawasan dan transportasi. Teori kelompok berisiko menyatakan bahwa lansia sangat berisiko mengalami berbagai masalah kesehatan termasuk kekerasan. Kekerasan fisik dan psikologis pada lansia terkadang tidak cepat disadari, bahkan menjadi sebuah 'budaya' karena ketidaktahuan atau rendahnya pengetahuan.

Oleh karena itu, kekerasan fisik dan psikologis yang terjadi pada lansia sering kali dilakukan oleh orang-orang terdekat yang berada di sekitarnya dan sulit untuk di survey karena dijadikan sebuah kebiasaan oleh beberapa kelompok. Beberapa tempat menjadi sangat berisiko terjadi kekerasan, antara lain lembaga pemsayarakatan, institusi tertentu dan hotel "single'. Lembaga pemasyarakatan atau lapas adalah tempat berisiko terjadinya kekerasan pada lansia. Berbagai penelitian meyebutkan bahwa kekerasan dapat menyebabkan penurunan kualitas hidup pada lansia.

\section{Metode Penelitian}

Metode penelitian yang digunakan adalah deskriptif research tanpa kelompok kontrol. Penelitian ini dilakukan di Lembaga Pemasyarakatan Banten yang merupakan LP dengan narapidana terbanyak dan over capacity. Adapun populasi penelitian yaitu penghuni /narapidana Lembaga Pemasyarakatan kelas 1, sedangkan sampel penelitian sebanyak 36 responden yang dipilih dengan kriteria inklusi kelompok lanjut usia baik lansia muda usia 60-69 tahun dan lansia 
tua $>70$ tahun. Pengumpulan data dilakukan dengan menggunakan kuesionair. Selanjutnya, data yang didapat dilakukan analisa data dan hasil penelitian disajikan dalam bentuk distribusi frekuensi dan proporsi.

\section{Hasil Penelitian}

\section{Karakteritik Lansia}

Tabel 1 Distribusi Karakteristik narapidana lansia lapas Kelas I, Tangerang pada bulan Mei $2016(n=36)$

\begin{tabular}{lcc}
\hline \multicolumn{1}{c}{ Karakteristik } & Frekuensi (n) & Presentase (\%) \\
\hline Usia & & \\
Lansia muda 60-69 thn & 28 & 77,78 \\
Lansia tua > 70 thn & 8 & 22,22 \\
Suku & 5 & 13,89 \\
Jawa & 17 & 47,22 \\
Sunda & 4 & 11,11 \\
Betawi & 2 & 5,55 \\
Batak & 3 & 8,33 \\
Tionghoa & 5 & 13,89 \\
$\quad$ Lainnya & & \\
\hline \multicolumn{1}{c}{ Total } & 36 & 100 \\
\hline
\end{tabular}

Berdasarkan tabel 1 menunjukan bahwa narapidana lansia yang ada di LAPAS paling banyak berada pada kelompok umur lansia muda (60-69 thn) sebanyak 77,78\% dan Narapidana lansia dari suku Sunda adalah responden terbanyak sebesar 47,22\%.

\section{Insiden Perilaku Kekerasan Fisik}

Tabel 2 Distribusi kejadian kekerasan fisik pada narapidana lansia di lapas kelas I, Tangerang.

\begin{tabular}{lcc}
\hline \multicolumn{1}{c}{ Kategori } & Jumlah (f) & Presentase (\%) \\
\hline Terjadi kekerasan & 15 & 41,67 \\
Tidak terjadi kekerasan & 21 & 58,33 \\
\hline \multicolumn{1}{c}{ Total } & 36 & 100 \\
\hline
\end{tabular}

Berdasarkan tabel 2 menunjukan bahwa narapidana lansia di lembaga pemasyarakatan paling banyak tidak mengalami kekerasan fisik yaitu sebesar 58,33\%.

\section{Gambaran kekerasan fisik berdasarkan usia}

Tabel 3 Distribusi kejadian kekerasan fisik pada narapidana lansia di lapas berdasarkan usia pada bulan Mei $2015(n=36)$

Kategori Lansia muda Lansia tua




\begin{tabular}{ccccc}
\hline & $(\mathbf{f})$ & $(\mathbf{\%})$ & $(\mathbf{f})$ & $\mathbf{( \% )}$ \\
\hline Terjadi kekerasan & 10 & 35,71 & 5 & 62,5 \\
Tidak terjadi kekerasan & 18 & 64,29 & 3 & 37,5 \\
\hline Total & 28 & 100 & 8 & 100 \\
\hline
\end{tabular}

Berdasarkan tabel C.3. menunjukan bahwa narapidana dengan kategori lansia tua lebih banyak terjadi kekerasan fisik (62,5\%). Hal ini berbanding terbalik dengan hasil kategori lansia muda yang angka kejadian kekerasan fisik lebih rendah $(35,71 \%)$

\section{Gambaran kekerasan fisik berdasarkan suku}

Tabel 4 Distribusi kejadian kekerasan fisik pada narapidana lansia di lapas berdasarkan suku pada bulan Mei $2015(n=36)$

\begin{tabular}{lcccccccccccc}
\hline \multirow{2}{*}{ Suku } & \multicolumn{2}{c}{ Jawa } & \multicolumn{2}{c}{ Sunda } & \multicolumn{2}{c}{ Betawi } & \multicolumn{2}{c}{ Batak } & \multicolumn{2}{c}{ Tionghoa } & \multicolumn{2}{c}{ lainnya } \\
\cline { 2 - 14 } & f & $\%$ & $\mathrm{f}$ & $\%$ & $\mathrm{~F}$ & $\%$ & $\mathrm{~F}$ & $\%$ & $\mathrm{~F}$ & $\%$ & $\mathrm{f}$ & $\%$ \\
\hline $\begin{array}{l}\text { Terjadi } \\
\text { kekerasan }\end{array}$ & 2 & 33,33 & 9 & 52,94 & 1 & 25 & 0 & 0 & 2 & 66,77 & 1 & 25 \\
$\begin{array}{l}\text { Tidak } \\
\text { terjadi } \\
\text { kekerasan }\end{array}$ & 4 & 66,67 & 8 & 47,06 & 3 & 75 & 2 & 100 & 1 & 33,33 & 3 & 75 \\
\hline \multicolumn{1}{c}{ Total } & 6 & 100 & 17 & 100 & 4 & 100 & 2 & 100 & 3 & 100 & 4 & 100 \\
\hline
\end{tabular}

Tabel 4 menunjukan bahwa narapidana lansia dengan dengan suku Sunda dan Tionghoa memiliki angka kekerasan fisik lebih tinggi. Lansia dengan suku Sunda terjadi kekerasan fisik sebesar 52,94\% dan Tionghoa sebesar 66,77\%.

Insiden kekerasan psikologis

Tabel 5 Distribusi kejadian kekerasan psikologis pada narapidana lansia di lapas Jawa Barat berdasarkan usia pada bulan Mei $2015(n=36)$

\begin{tabular}{ccc}
\hline \multicolumn{1}{c}{ Kategori } & Jumlah (f) & Presentase (\%) \\
\hline Terjadi kekerasan & 13 & 36,11 \\
Tidak terjadi kekerasan & 23 & 63,89 \\
\hline Total & 36 & 100 \\
\hline
\end{tabular}

Berdasarkan tabel 5 menunjukan bahwa narapdana lansia di lembaga pemasyarakatan paling banyak tidak terjadi kekerasan psikologis sebesar $63,89 \%$.

\section{Gambaran kekerasan psikologis berdasarkan usia}

Tabel 6 Distribusi kejadian kekerasan psikologis pada narapidana lansia di lapas berdasarkan usia pada bulan Mei $2015(n=36)$

\begin{tabular}{|c|c|c|c|c|}
\hline \multirow{2}{*}{ Kategori } & \multicolumn{2}{|c|}{ Lansia muda } & \multicolumn{2}{|c|}{ Lansia tua } \\
\hline & (f) & $(\%)$ & (f) & $(\%)$ \\
\hline Terjadi kekerasan & 10 & 25,8 & 3 & 37,5 \\
\hline
\end{tabular}

Jurnal SMART Keperawatan Sekolah Tinggi Ilmu Kesehatan (STIKes) Karya Husada Semarang 


\begin{tabular}{ccccc} 
Tidak terjadi kekerasan & 18 & 64,2 & 5 & 62,5 \\
\hline Total & 28 & 100 & 8 & 100
\end{tabular}

Dari tabel 6 menunjukan bahwa narapidana dengan kategori lansia tua dan muda di lembaga pemasyarakatan lebih banyak tidak mengalami kekerasan psikologis. Narapidana lansia muda tidak mengalami kekerasan psikologis sebesar 64,2\% sedangkan narapidana dengan kategori lansia tua sebesar $62,5 \%$.

\section{Gambaran kekerasan psikologis berdasarkan suku}

Tabel 7 Distribusi kejadian kekerasan psikologis pada narapidana lansia di lapas Jawa Barat berdasarkan suku pada bulan Mei $2015(\mathrm{n}=36)$

\begin{tabular}{|c|c|c|c|c|c|c|c|c|c|c|c|c|}
\hline \multirow{2}{*}{ Suku } & \multicolumn{2}{|c|}{ Jawa } & \multicolumn{2}{|c|}{ Sunda } & \multicolumn{2}{|c|}{ Betawi } & \multicolumn{2}{|c|}{ Batak } & \multicolumn{2}{|c|}{ Tionghoa } & \multicolumn{2}{|c|}{ lainnya } \\
\hline & $\mathrm{N}$ & $\%$ & $\mathrm{n}$ & $\%$ & $\mathrm{n}$ & $\%$ & $\mathrm{~N}$ & $\%$ & $\mathrm{~N}$ & $\%$ & $\mathrm{n}$ & $\%$ \\
\hline $\begin{array}{l}\text { Terjadi } \\
\text { kekerasan }\end{array}$ & 0 & 0 & 8 & 47,05 & 1 & 25 & 1 & 50 & 1 & 33,3 & 2 & 50 \\
\hline $\begin{array}{l}\text { Tidak } \\
\text { terjadi } \\
\text { kekerasan }\end{array}$ & 6 & 100 & 9 & 52,95 & 3 & 75 & 1 & 50 & 2 & 66,7 & 2 & 50 \\
\hline Total & 6 & 100 & 17 & 100 & 4 & 100 & 2 & 100 & 3 & 100 & 4 & 100 \\
\hline
\end{tabular}

Tabel 7 menunjukan bahwa narapidana lansia dengan suku yang diteliti oleh peneliti, tidak terjadi kekerasan.

\section{Pembahasan}

\section{Kejadian kekerasan fisik dan psikologis pada narapidana lansia}

Hasil penelitian ini menunjukkan bahwa narapidana lansia di lembaga pemasyarakatan sebagian besar tidak tejadi kekerasan fisik (58,33\%). Kekerasan fisik pada lansia adalah tindakan sengaja yang dilakukan untuk melawan kekuatan lansia sehingga menimbulkan nyeri fisik atau cidera (Singh, 2014). Hasil penelitian ini sesuai dengan penelitian yang dilakukan oleh Hartati (2006) dengan hasil bahwa tidak ada budaya kekerasan di lembaga pemasyarakatan tangerang terhadap narapidana anak wanita. Kekerasan fisik biasanya diikuti dengan kekerasan psikologis (Lachs \&Pillemer, 2014). Pernyataan Lachs dan Pillmer (2014) sesuai dengan hasil kekerasan psikologis bahwa sebagian besar narapidana lansia tidak mengalamai kekerasan psikologis $(63,89 \%)$. Kekerasan psikologis adalah seseorang yang dengan bebas mengancam, menghina, mentertawakan, mengabaikan, dan menteror lansia baik secara verbal maupun non verbal sehingga menyebabkan sakit hati, kesedihan yang mendalam atau stres (Singh, 2014; Daphne, 
2011). Miller (2012) menyatakan bahwa kualitas hidup lansia terjadi apabila adanya penuruan kekerasan yang terjadi.

Hasil penelitian ini juga mengidentifikasi bahwa beberapa pernyataan yang dapat menjadi faktor risiko terjadinya kekerasan fisik lebih tinggi adalah pernyataan "saya dipukul atau didorong oleh seseorang di dalam lapas". Responden sebagian besar fokus pada perilaku mendorong, karena menurut mereka frekunesi memukul dapat dikatakan tidak pernah terjadi, hanya beberapa orang saja pernah mengalami perlakuan tersebut. Salah satu keterangan dari responden mengenai terjadinya perilaku mendorong adalah ketika masuk kamar dan ketika makan. Peneliti tidak melihat secara langsung adanya tanda-tanda kekerasan fisik tersebut. Tanda lansia yang mengalami kekerasan fisik adalah adanya memar, terdapat tanda jeratan tali atau benda tumpul atau tajam lainnya, tejadi cidera berulang kali tanpa alasan yang jelas, menolak untuk berobat, dan terdapat benjolan (APA, 2012; Hoglund \&Olson, 2014).

Hasil penelitian juga menyatakan bahwa meskipun angka kekerasan fisik pada narapidana lansia di lembaga pemasyarakatan jarang ditemukan, namun lansia dan lembaga pemasyarakatan sebagai kelompok berisiko harus tetap dilakukan tahap pencegahan oleh lembaga pemasyarakatan. Pencegahan yang dilakukan dapat bersifat pengawasan dari pertugas lapas dan pengelompokan narapidana lansia dalam satu sel. Pemerintah dalam hal ini dapat menjaga kestabilan kapasitas lembaga pemasyarakatan, karena salah satu penyebab terjadinya kekerasan adalah jumlah penghuni yang melibihi kapasitas (Hartati, 2006).

Pernyataan mengenai kesedihan dan kesepian memiliki nilai paling rendah dibandingan pernyataan lain atau berisiko terjadinya kekerasan psikologis. Penelitian Daphne (2010) mengenai hubungan anatara rasa kesepian dan tingkat terjadinya kekerasan, didapatkan kesimpulan bahwa lansia yang mengalami rasa kesepian dapat terjadi kekerasan fisik dan psikologis. Banyak faktor lain yang menyebabkan kesedihan dan kesepian yang dirasakan oleh lansia, salah satunya adalah keterbatasan berinteraksi dengan keluarga dan dunia luar. Hicks (2000) menyatakan bahwa kesepian yang terjadi pada lansia akan meningkat apabila berkurangnya hubungan dengan kerabat; meningkatnya ketergantungan; dan hilangnya teman, rumah, kebebasan dan identitas diri. Sebagian besar responden lebih banyak menghabiskan waktu dengan cara beribadah. Ibadah merupakan salah satu dari praktik kegamaan.

Penelitian Doris, Margaret dan Risa (2000) didapatkan bahwa agama dan praktik keagamaan dapat menjadi sistem pendukung spiritual individu. Spiritual adalah hubungan diri 
sendiri dengan yang lain dan sesutu yang bersifat maha kuat dan tinggi. Menurut teori Fowler dalam Ladner \&Delune (2011) menyebutkan bahwa tahap perkembangan spiritual lansia berada pada universalizing faith atau umumnya individu merasa puas dengan kepercayaan yang dianutnya, pada tahap ini individu akan memelihara spiritualnya dengan cara melakukan praktik spiritual atau kegiatan sesuai yang dipercayainya.

Penelitian Bryant dan Davis (2005) didapatkan bahwa agama dan spiritual dapat menjadi strategi koping yang bisa memperbaiki trauma tiap individu. Peneliti menyimpulkan bahwa agama dan praktik spiritual yang dilakukan oleh lansia adalah strategi koping untuk mengatasi masalah fisik maupun psikologis yang dialami selama di lembaga pemasyarakatan. Penelitian Nofitri (2009) didapatkan hasil bahwa pelayanan petugas lembaga pemasyarakatan berada dalam kategori cukup puas. Aspek penelitian tersebut terdiri dari sikap, cara berpakaian, dan komunikasi petugas. Pelayanan petugas lapas terhadap narapidana lansia dapat mengindikasikan penurunan angka kekerasan, sehingga petugas berperan penting dalam hal pencegahan masalah.

\section{Kekerasan fisik dan psikologis berdasarkan usia}

Hasil penelitian ini menunjukan bahwa perbandingan lansia dengan kategori lansia muda dan lansia tua, lansia dengan kategori tua lebih banyak terjadi kekerasan fisik $(62,5 \%)$ dan psikologis (37,5\%). Berbanding terbalik dengan lansia muda yang angka kejadian kekerasan fisik $(35,71 \%)$ dan psikologis $(25,8 \%)$ atau dikatakan bahwa lansia dengan kategori muda paling banyak tidak mengalami kekerasan fisik dan psikologis. Hal tersebut karena penambahan usia pada individu dapat meningkatkan tingkat resiko terjadinya masalah kesehatan termasuk kekerasan (Stanhope \&Lancaster, 2004 ;Potter \&Perry, 2009). Penurunan kemampuan fungsional dapat mempengaruhi kualitas hidup seseorang (Astuti, 2013). Dilihat dari usianya lansia tua memiliki kualitas hidup lebih rendah dibandingkan dengan lansia muda. Lembaga pemasyarakatan memberikan remisi bagi narapidana berusia 70 tahun lebih.

\section{Kekerasan fisik dan psikologis berdasarkan suku}

Hasil penelitian ini didapatkan bahwa angka kekerasan suku Sunda paling tinggi pada dua variabel yaitu kekerasan fisik sebesar 52,94\% dan psikologis sebeasar 47,05\%. Lansia dengan suku Sunda meskipun kelompok mayoritas tapi memiliki angka kekerasan fisik dan psikologis tinggi. Hal ini tidak sesuai dengan konsep vulnerable population bahwa lansia dengan etnik minor masuk ke dalam kelompok rentan. Peneliti menganalisa bahwa lembaga pemasyarakatan Indonesia sudah menerapkan manajemen konflik antar etnik. Responden mengatakan bahwa 
narapidana dewasa lebih segan dan hormat terhadap mereka.

\section{Kesimpulan}

Karakteristik lansia pada penelitian ini sebagian besar berada pada kelompok lansia muda, berjenis kelamin laki-laki dan berasal dari suku sunda. Narapidana lansia yang tidak tidak terjadi kekerasan fisik lebih banyak daripada lansia yang terjadi kekerasan fisik. Narapidana lansia yang tidak terjadi kekerasan psikologis lebih banyak daripada lansia yang terjadi kekerasan psikologis. Narapidana dengan kategori lansia tua lebih banyak terjadi kekerasan fisik daripada lansia dengan kategori muda. Narapidana dengan suku Sunda paling banyak terjadi kekerasan psikologis, dan narapidana suku Sunda dan Tionghoa paling banyak terjadi kekerasan fisik.

\section{Saran}

\section{Kementrian hukum dan hak asasi manusia}

Membuat kebijakan untuk pencegahan kekerasan lansia di lembaga pemasyarakatan dengan tiga tahap yaitu primer, skunder dan tersier. Pencegahan primer dengan cara memisahkan kamar narapidana lansia dengan narapidana dewasa, memberikan pendidikan manajemen konflik dan fokus pengawasan oleh petugas. Pencegahan sekunder dilakukan dengan cara melakukan program aduan bagi lansia yang telah mengalami kekerasan. Pencehagan tersier dengan merehabilitasi pelaku dan lansia yang terlibat dalam kekerasan.

\section{Pelayanan kesehatan}

Perawat lapas dapat memberikan edukasi kepada penghuni lapas lainnya dan petugas keamanan terkait kekerasan pada lansia, selain itu dapat memberikan motivasi kepada petugas keamanan dalam memperhatikan dan mengawasi secara khusus narapidana lansia,

Perawat dan dokter lapas melakukan cek kesehatan berkala bagi narapidana lansia, Psikolog lapas dapat melakukan konseling secara berkala terhadap lansia.

\section{Daftar Pustaka}

Age, UK. (2013). Factsheet: Safeguarding older people from abuse. England.

American Psychological Association. (2012). Elder Abuse \&Neglect: in search of solution. Washington, DC: American Psychological Association. 
Aileen, W., Carolyn, E. Z., Racilia, Laura, M., Linda, R. P.(2013). Injury Patterns and Causal Mechanisms of Bruising in Physical Elder Abuse. International Association of Forensic Nurses.

Benjamin, A. E, Matthias, R. E., (2013). Health \& Social Work: Abuse and neglect of clients in agency-based and consumer-directed home care. Silver Spring: Oxford University Press. Tersedia di Basis data tesis dan disertasi ProQuest. (ProQuest document ID: 210549232).

Greifinger, Mellow, Safer, Sterns, \&William. (2012). Aging in Correctional Custody: Setting a Policy Agenda for Older Prisoner Health Care. Washington: American Public Health Association.

HealthLinkBC. (2014). Abuse and Neglect of Older Adults: Understanding gender differences. Columbia.

Hoglund, B. A., Olson, J. M., (2014). Elder Abuse: Speak out for justice. InterVarsity Christian Fellowship.

Komisi Nasional Lanjut Usia. (2010). Profil Penduduk Lanjut Usia 2009. Jakarta: Komnas Lansia.

Kosberg, Jordan. (2014). Journal of Elder Abuse \& Neglect: The abuse of elderly men. New York: Taylor \& Francis Group.

Liwarti. (2013). Hubungan Pengalaman Spiritual dengan Psychological Well being pada Penghuni Lembaga Pemasyarakatan. Malang.

Phelan, A., \&Treacy, M. P. (2011). A Review of Elder Abuse Screening Tools for Use in the Irish Context. Dublin: National Centre for the Protection of Older People.

Stanley, M. \& Bare, P. G. (2002). Gerontological Nursing: a Health Promotion/ Protection Approch. $2^{\text {nd }}$ ed. Philadephia: F. A. Davis Company.

United Nation (UN). (2012). Population Ageing and Development 2012. New York : Population Division Department of Economic and Social Affairs United Nation.

Wallace, M. (2008). Essentials of Gerontological Nursing. New York: Springer Publishing Company. 